\title{
鋼橋の高カボルト軸力診断への カオス理論の適用に関する研究
}

\author{
広兼道幸 ${ }^{1}$, 大江眞紀子 $^{2}$, 小西日出幸 ${ }^{3}$, 鈴木直人 $^{4}$ \\ 1正会員 関西大学教授 総合情報学部（†569-1095 大阪府高槻市霊仙寺2-1-1） \\ E-mail:hirokane@res.kutc.kansai-u.ac.jp \\ 2非会員 関西大学大学院 総合情報研究科（†569-1095 大阪府高槻市霊仙寺2-1-1） \\ E-mail:imoimomaturi3@gmail.com \\ 3正会員 日本橋梁株式会社 技術開発室（干675-0164 兵庫県加古郡播磨町東新島3 \\ E-mail:konishi@nihon-kyoryo.co.jp. \\ 非会員 日本橋梁株式会社 技術開発室（干675-0164 兵庫県加古郡播磨町東新島3） \\ E-mail:n-suzuki@nihon-kyoryo.co.jp.
}

\begin{abstract}
現在, 高度経済成長期に建造された構造物の老朽化が進み, 維持管理対象にある構造物の数が急激に増 加している．橋梁も例外ではなく，日本の50年経過橋梁の数は，2011年時点で全体の9\%の約 15,000 橋であ るが，2021年には28\%に相当する44,000橋，更に10年後には53\%にも上る84,000橋にまで増加する見込みで ある。その中で，鋼橋の架設に利用されている高力ボルトも時間経過と共に緩みが発生するため，定期的 に点検する必要がある，様々な点検方法の中で，打音法は低コストで危険を伴わず，簡便に作業を行うこ とができ，信頼性の高いよく使われる点検法である。しかしこの方法は熟練者の勘や経験に依る部分があ る．そのため非熟練者でも高い精度で診断できることを目的として，打音データからアトラクタを構築し 定量的に評価することで状態識別を試みた.
\end{abstract}

Key Words : steel bridge, high-strength bolts, impact acoustics, chaos theory, attractor analysis

\section{1. はじめに}

現在，高度経済成長期に建造された構造物の老朽化が 進み, 維持管理対象にある構造物の数が急激に増加して いる．橋梁も例外ではなく，日本の50年経過橋梁の数は 2011年で全体の9\%の約15,000橋だが，2021年には28\%に 相当する44,000橋，更に10年後には53\%にも上る84,000橋 にまで増加する見込みである1)。この様に橋梁全体の経 年劣化が進む中で，1960年代から鋼橋の架設に利用され ている高力ボルトも時間経過と共に腐食や疲労により， 緩みが発生するため定期的に点検する必要がある.

高力ボルトの緩みを点検するためにひずみゲージや超 音波等 ${ }^{2}$ 種々の非破壊検査法が利用されている。しかし， これらの方法の多くは、ボルトの抜き取りを前提とし, 測定精度を確保するため, 事前加工処理が必要になるな ど，施工性に問題がある。一方，抜き取りをしない方法 については, 精度確保に問題がある. この問題の解決方 法として打音法を利用すれば，低コストで危険を伴わず 簡便に作業を行うことが可能である. 従来の打音法は, 高力ボルトのナット側をハンマで打撃し, 熟練者が打音
を聞き分けることによって異常を検知するものである. しかし，この方法は熟練者の勘や経験に依る部分がある ため，経験者とはいえ客観性に乏しい. 同時に熟練技術 者の減少による人材不足の問題も抱えている.

そこで本研究では，非熟練者でも高い信頼性を保ちつ つ，容易により正確な軸力診断が出来るデータ分析法の 確立を目指す，提案する方法は，様々な分野において有 用性が確認されているカオス時系列解析法3)(4),5)を用いて， 定量的評価を行うもので，打音データを分析し，ボルト の軸力の識別を行う. さらに, 識別精度の定量的評価を 行う際，小西らが行った文献6において得られた打音分 析の結果との比較を行った.

\section{2. システムの概要}

本システムは高力ボルトをハンマで打撃した際に発生 する打音データに対して，カオス時系列解析法を用いて 定量的評価を行い，軸力の識別を行う。まず，打音デー タに対して，アトラクタ解析を行う。次に，アトラクタ 解析の結果に対して, 相関次元法を用いて相関指数を算 
出することで定量的評価を行う．予めサンプルの打音デ 一タから相関指数の平均を求め, 識別に適した次元を決 定した後，各サンプルの同次元上の相関指数を比較する ことによって, 軸力ごとの閾值を決定する. その後, 求 めた識別に適した次元において, テストデータと閾值を 比較し, 軸力を推定する.

\section{(1) アトラクタ解析}

アトラクタとはエネルギーの散逸を伴う一般システム において，定常的に長時間安定して観測し続けるシステ ムの状態のことである.ある散冕系のシステムにおいて， その状態変数（時々刻々のシステムの状態を表す数字の 組）を多次元再構成状態空間上にプロットしていくと， そのシステムの過渡状態経過後の定常状態を表すアトラ クタを見つけることが出来る．また，カオス性を有する 時系列から再構成されたアトラクタはストレンジアトラ クタとなる゙).

本研究では，打音データに対して遅れ時間をとること によって多次元状態空間に埋め込み位相構造を確認寸る。 埋め込み方法はタケンスの定理を利用する. タケンスの 定理は等間隔で得られた1変数の時系列データから多次 元状態空間に埋め込む操作である.

\section{(2) 相関次元法}

相関次元法とはフラクタル次元を算出する手法の一つ である.フラクタルとはフランスのMandelbrotにより考 え出されたもので, 複雑な形状の乱雑さを数值化して表 現するための概念である7,8).海岸線のような図形をある 物差しで測った長さを $r$, 同じ物差しで測った回数を $N(r)$ とした時

$$
N(r) \propto r D
$$

が成立する. この $D$ をラクタル次元と呼び，フラクタ ル次元が大きいほど図形は複雑であるとされる.アトラ クタのフラクタル次元を決定することで，カオス性を有 する時系列データを特徽付けることができる.

相関次元法によるフラクタル次元の求め方は, データ を埋め込むための次元 $n$ を変化させつつ累積分布関数 $C(r)$ を求める. $N$ をサンプリング数とし, $C(r)$ は 2 体相 関関数の積分

$$
\begin{aligned}
& C(r)=\frac{1}{N^{2}} \sum_{i \neq j} H\left(r-\left\|\overrightarrow{x_{\imath}}-\overrightarrow{x_{J}}\right\|\right) \\
& H(z)= \begin{cases}1(z \geq 0) \\
0(z<0)\end{cases}
\end{aligned}
$$

を考える. 元のデータがカオス性を有しているならば, $\log r$ と $\log C(r)$ は次元数を増やしても整数でない定数 になるため, 両対数グラフの直線部の傾き $v$ から各埋め 込み次元数の相関指数の変化を求め, 值が飽和した位置 をそのデータのフラクタル次元とできる.

\section{3. 分析に利用する打音データ}

本研究では，文献6)で用いた打音データの一部を利用 する．利用したデータは，文献6)の打音データ取得方法 の検証において最も識別率の高かったデータの採取環境 である，市販されている1.3kgのセットハンマでナット 辺を打撃し，内側に設置したマイクで集音した打音デー 夕を利用することにした，データ数は軸力 $100 \% ， 80 \%$, 60\%の各5回分，計15回分である.これらのうち，各3回 分のデータから相関指数を求めることによって, 軸力識 別の閾值を求める. そして, 残りの各2回分をテストデ 一タとし識別実験を行う．打音データを採取する際に使 用した要素試験体や採取方法，検証結果を以下に述べる.

\section{(1) 打音データ採取の要素試験体}

打音データを採取する際に利用した高力ボルトの要素 試験体を図-1に示寸，要素試験体は，図-1のような高力 ボルトを1本のみ締め付けたものを，架台に溶接で固定 したものである.ひずみゲージで軸力を測定するために 軸部に間を設けている. 高力ボルトは一般的に使用され てきた，材質F10T，径M22とし，首下長さは標準的な 85mmのものである.

\section{(2) 打音データの採取方法}

要素試験体の高力ボルトを設置した状況を図-2に示寸。 通常の施工要領と同様にトルクレンチで設計軸力 (206kN)の60\%程度で予備締めを行った後, ひずみゲージ で軸力を測定しつつ設計軸力を目安に本締めを行ってい る. 小西らが行った研究)では, マイク位置やハンマの 種類，吒く箇所などを変えて，どのような条件であれば 最適な打音データが採取できるのかを検証している.

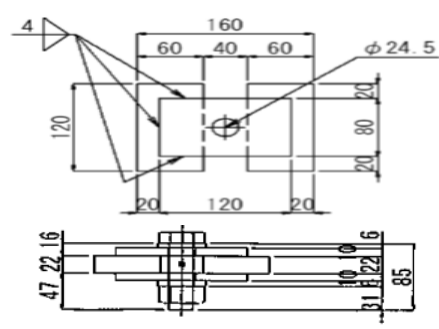

図-1 要素試験体図 


\section{(3) 既存研究の検証方法と結果}

打音データ採取時の条件を表-1 に示寸. 表-1 の各条 件において打音データを 5 回ずつ採取している. 採取し た打音データを周波数データに変換するために高速フー リエ変換を適用し，ハールウェーブレット変換でノイズ を除去した．変換した周波数データを条件別に比較しな がら，周波数分析を行った. 検証の結果，吒く強さに関 係なく, 打音データ採取の際にはナット辺を吒き，マイ クをボルト軸に隣接して設置寸れば比較的ノイズが少な く, 分析に有用な打音データが収集できることが分かっ た。

\section{4. 分析結果}

打音データからアトラクタを構築し, 軸力毎に比較を 行う。その後, 相関指数を求め, 軸力毎の閾值を決定す る. 最後にテストデータの相関指数と閾值を比較し, 相 関指数による識別が有用であるかを検証する.

\section{(1) 打音データの分析}

図-3，図-4，図-5 は打音診断の実験において得られ た軸力 $100 \% ， 80 \% ， 60 \%$ 時の打音データの一例である. 横軸は時間，縦軸は振幅である. 図-3，図-4，図-5を

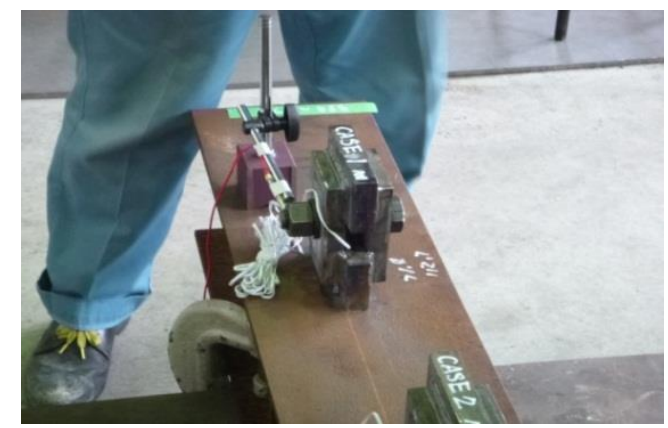

図-2 試験体設置状況（ナット側）

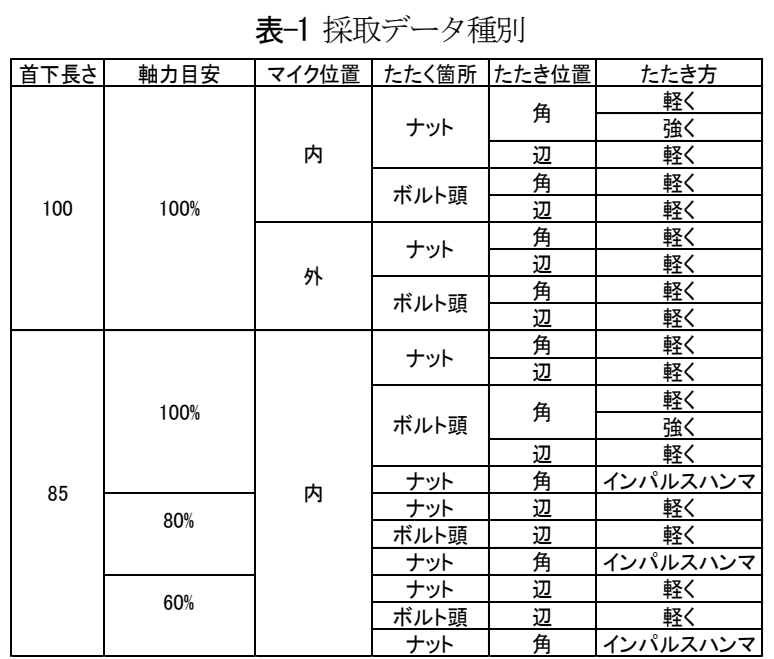

確認すると，振幅の大きさ自体は軸力に対して比例また は反比例などの関連性は見られないことが分かる.

また図-3，図-4，図-5 から，図-3 における初期振幅 からの減衰が増減を繰り返しながら小さくなっていくこ

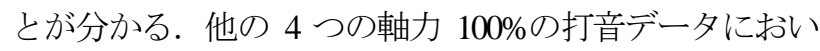
ても似たような変化が見られたため, 軸力 $100 \%$ の打音

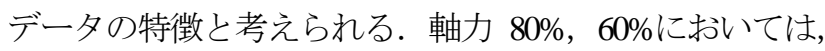
目視で減衰の特徵の違いを識別することができないが, 軸力 $100 \%$ と同様に減衰に特徽がある可能性が考慮され る. そのため, 軸力 $100 \%$ 時の打音データの最大振幅か ら約 $5 \%$ 未満に十分に収束するまでの 0.1 秒間を基準 ${ }^{4}$ に して，軸力の違いによる初期減衰に着目し，特徴を明ら かにするため, アトラクタを構成する.

\section{(2) アトラクタの構成}

元の打音データで確認できた減衰の特徽を視覚的に理 解するために，打撃により得られた時系列を遅れ時間を とって多次元状態空間に埋め込み，アトラクタを構成し た. アトラクタを構成する際の埋め込み作業はタケンス

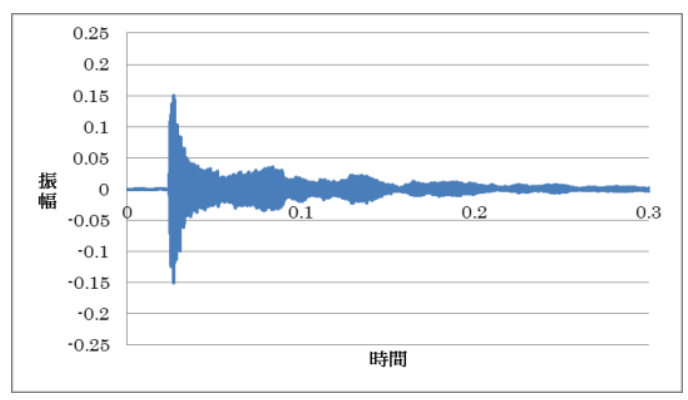

図-3 軸力 $100 \%$ 時の時系列データ

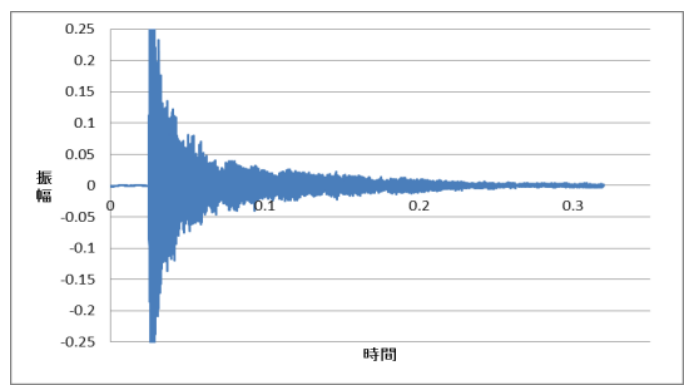

図-4 軸力 80\%時の時系列データ

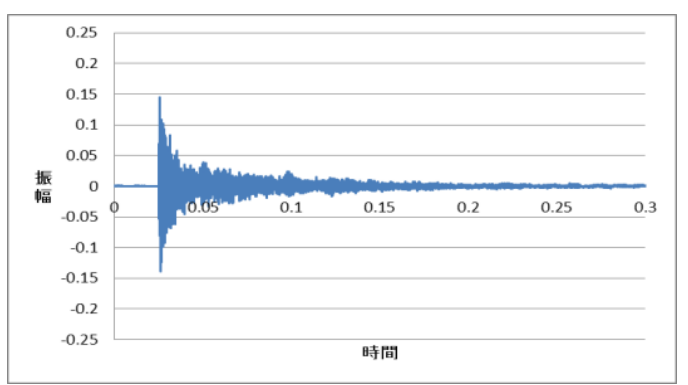

図-5 軸力 $60 \%$ 時の時系列データ 
の埋め込み定理 ${ }^{3)}$ に基づいている．埋め込みデータは時 系列データより各データの最大振幅から 0.1 秒後までを 等間隔で取り出した 256 点を使用する. 埋め込み次元は 2 次元とする. 遅れ時間に関しては時系列予測分野にお いて 1 が最適とされているために 1 に設定している ${ }^{5)}$.

図-3, 図-4, 図-5 のアトラクタ構成結果を図-6, 図-7, 図-8 に示寸. 図-6, 図-7, 図-8 から，軸力毎にアトラ クタの位相構造に差異が表れることが分かる. 軸力によ るアトラクタの傾向として，図-6 より，軸力 $100 \%$ の打 音データからは，左上と右下を往復するアトラクタが構 成されることが分かる．図-7 より，軸力 $80 \%$ の打音デ 一タからは潰れた楕円を描きながら，ややゆっくり収束 していることが分かる. 図-8 より，軸力 $60 \%$ の打音デ 一タからは，全体的に軌道が乱れながら収束しているこ とが分かる．同じ軸力の他のデータにおいても，微妙な 吒き方の強弱やノズの影響で多少の差異はあったが, 軸力が低くなる毎に収束時の乱れ方が不規則になりやす いことが分かった。しかし，軸力 $80 \%$ のアトラクタと軸 力 $60 \%$ のトラクタの違いは，視覚的には判別しにくい ものもあり，アトラクタの視覚化だけでは軸力を識別す るためには不十分と思われる，そのため，相関次元法に

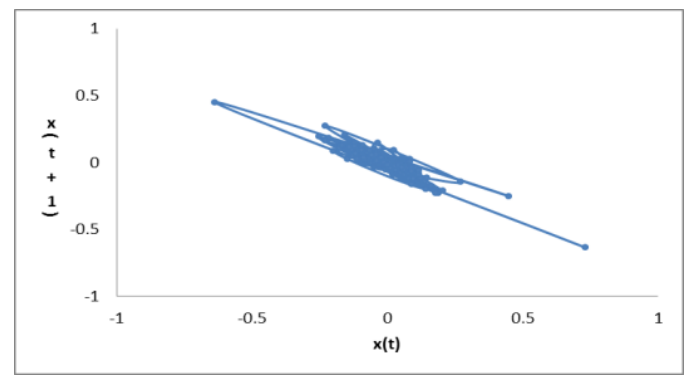

図-6 軸力 $100 \%$ 時のアトラクタ

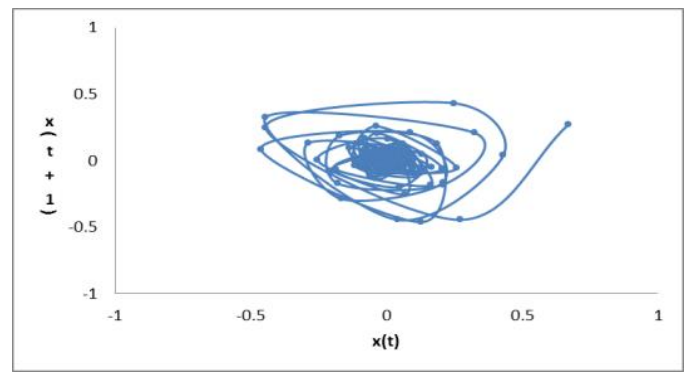

図-7 軸力 $80 \%$ 時のアトラクタ

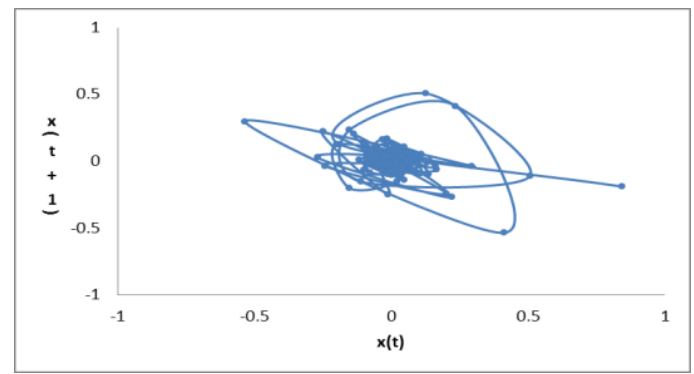

図-8 軸力 $60 \%$ 時のアトラクタ
より定量的評価を行うことによって，軸力の違いによる 特性の違いを明らかにした。

\section{(3) 相関次元による分析}

軸力 $100 \%$ のトラクタのデータの一つから埋め込み 次元を変化させた $C(r)$ と $r$ の関係を両対数グラフで表す と図-9のようになった. 図-9のグラフの直線部の傾き から相関指数vを算出する.このグラフは 8 次元まで示 しているが，実際の計算では 15 次元まで求め傾きを概 算している，例として，図-10 は軸力 $100 \%$ の中ら 3 回分の打音データを取り出し，各次元に対する相関指数 の值を示したものである. 同様の処理を全データで行い， 算出された軸力ごとの平均を表-2に示す.

時系列データがカオス的挙動を取るならば次元が増加 しても相関指数 $v$ の值は飽和するため，ある一定の值を 保つ.しかし，本研究の打音データは一度の打撃から得 られるものである．時間経過と共に振幅が減衰し，やが て原点に収束してしまうため，定常的にカオス性を有す るとは考えにくい，また，相関次元法はノイズに敏感で あり相関指数vはノイズがあると低次元上では值が飽和 せず，次元に比例して大きくなり，フラクタル次元を決 定することができない，今回採取した打音データも定常 的なカオスではなく, 図-10を見ると值が収束しないこ とからノイズが含まれていることが分かる，さらに，相 関指数 $v$ は次元の増加と共に值が増加している.

そのため相関指数 $v$ からのフラクタル次元の決定は困 難である. そのため本研究では定量的に評価するための 指標として，アトラクタを基に算出したフラクタル次元 ではなく，相関次元法でフラクタル次元を求める際に算 出した相関指数 $v$ を比較する. 表-2 の平均值をグラフ

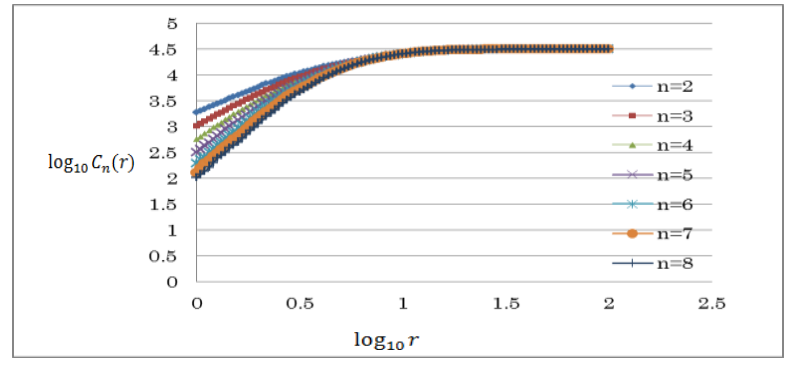

図-9 両対数グラフ

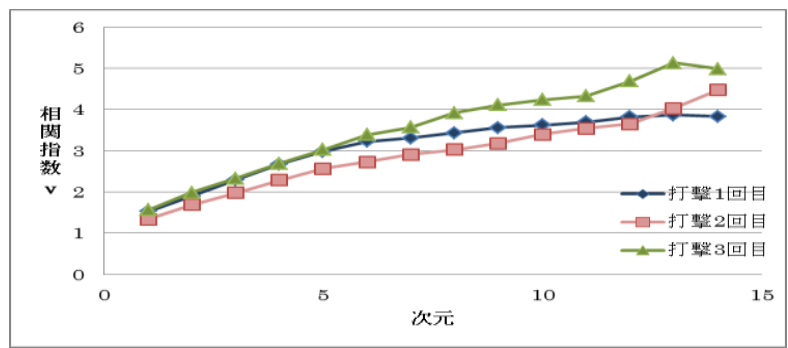

図-10＼cjkstart次元別相関指数データ $(100 \%)$ 
表-2 次元別相関指数の平均值(ナット辺)

\begin{tabular}{|c|c|c|c|c|c|c|c|c|c|c|c|c|c|c|}
\hline †惻関指数 & 2 & 3 & 4 & 5 & 6 & 7 & 8 & 9 & 10 & 11 & 12 & 13 & 14 & 15 \\
\hline $100 \%$ & 1.47594 & 1.85580 & 2.19877 & 2.55077 & 2.85837 & 3.11158 & 3.25916 & 3.46034 & 3.61427 & 3.74981 & 3.85375 & 4.05380 & 4.34440 & 4.42692 \\
\hline $80 \%$ & 1.76283 & 2.45697 & 3.20077 & 3.86936 & 4.51095 & 4.84854 & 5.35613 & 5.77421 & 6.06061 & 6.66302 & 6.76470 & 7.15250 & 7.12871 & 7.32451 \\
\hline $60 \%$ & 1.74195 & 2.46659 & 3.12408 & 3.73042 & 4.57676 & 5.32680 & 6.14199 & 6.64561 & 7.24605 & 7.02655 & 7.36873 & 7.85969 & 7.83610 & 7.94720 \\
\hline
\end{tabular}

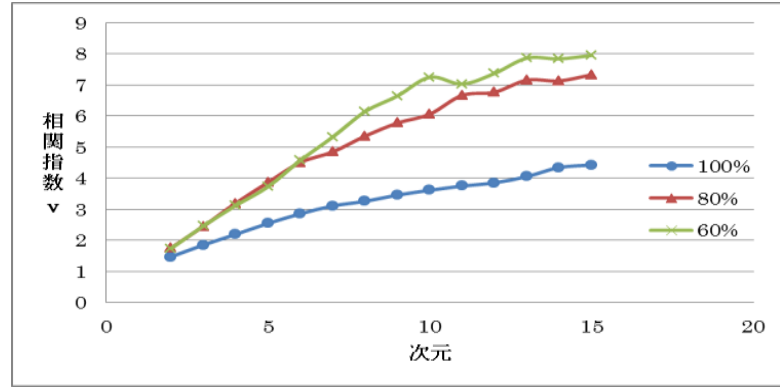

図-11 次元別相関指数平均グラフ（ナット辺）

表-3 学習用データの相関指数の值の例

\begin{tabular}{|c|c|c|c|c|}
\hline & \multicolumn{3}{|c|}{ 軸力 } \\
\hline & & $100 \%$ & $80 \%$ & $60 \%$ \\
\hline \multirow{3}{*}{ 回数 } & 1 & 3. 5622154 & 6.3778606 & 6. 9544323 \\
\hline & 2 & 3.1741658 & 5. 4071560 & 7.9582768 \\
\hline & 3 & 4. 1064416 & 6.3968217 & 6.8254476 \\
\hline
\end{tabular}

化したものが図-11 となる. 図-11 を見ると高次元上に おいて，軸力によって相関指数 $v$ に差があることが分 かる. また, 軸力 $60 \%$ の相関指数 $v$ は 11 次元で一度小 さくなり 10 次元で值が飽和する傾向が見られ，軸力別 に明確に差が出ていることが分かる，さらに，フラクタ ル次元はノイズに敏感であり, 特に低次元だと判別が困 難になる.これらのことから，今回の実験では 10 次元 に埋め込んだアトラクタの相関指数 $v$ を分析に利用する こととした. 10 次元における相関指数 $v$ の各值は表 -3 のようになった. 表-3 より, 相関指数 $v$ の值は各軸力 で差があるため，軸力ごとに閾值を設定することにより， ある程度識別できることが分かる.

\section{(4) 識別実験}

本論文で提案した相関指数による識別がごの程度有効 か確かめるため，分析に利用した各軸力 5 回分の打音デ 一タから，3 回分の打音データをそれぞれランダムに選 び，全 9 種の打音データを学習用データとして，相関指 数を算出し軸力を識別するための閾值を求めた. 更に各 軸力の残り 2 回分の打音データ, 全 6 種の打音データを 評価用データとして, 学習用データによって求めた閾值 を使い軸力を求めた．例として，表-3 より軸力 $100 \%$ と $80 \%$ の識別時は $100 \%$ の最大值（4.10644）と $80 \%$ の最小 值（5.40715）の平均 4.75679 を，軸力 $80 \%$ と $60 \%$ の識別 時は 80\%の最大值（6.39682）と60\%の最小值（6.82544） の平均 6.61113 を閾值にしてして，軸力の識別に利用す
表-4 識別用データの相関指数の例

\begin{tabular}{|c|c|c|c|c|}
\hline \multicolumn{2}{|c|}{} & \multicolumn{3}{|c|}{ 軸力 } \\
\cline { 3 - 5 } \multicolumn{2}{|c|}{} & $100 \%$ & $80 \%$ & $60 \%$ \\
\hline \multirow{2}{*}{ 回数 } & 4 & 3.78370 & 4.92288 & 7.57194 \\
\cline { 2 - 5 } & 5 & 4.08589 & 6.16490 & 7.69415 \\
\hline
\end{tabular}

表-5 識別結果

\begin{tabular}{|c|c|c|c|c|}
\hline \multicolumn{2}{|c|}{} & \multicolumn{3}{|c|}{ 正解 } \\
\cline { 3 - 5 } \multicolumn{2}{c|}{} & 軸力100\% & 軸力 $80 \%$ & 軸力 $60 \%$ \\
\hline \multirow{3}{*}{ 分類 } & 軸力 $100 \%$ & 100 & 10 & 0 \\
\cline { 2 - 5 } & 軸力 $80 \%$ & 0 & 90 & 10 \\
\cline { 2 - 5 } & 軸力 $60 \%$ & 0 & 0 & 90 \\
\hline
\end{tabular}

ることにした．表-5 は，5回分の打音データから 3 回分 の学習データを取り出してくる 100 パターンで識別した 結果である. 表-5 から識別率は 90\%以上であり，相関 指数 $v$ によ識別は高い精度を持つことが分かる.

\section{(5) ボルト辺の検証}

文献 6)ではボルト頭を打撃することによって得られた 打音デー夕は識別に向かないとされているが提案手法で はどのような傾向が出るか調べた．前述した(1)，(2),

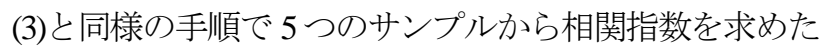
ところ, 次元別相関指数の平均は表-6 と図-12 のような 結果が得られた. 図-12 を見ると，軸力 $80 \%$ よりも $60 \%$ の值が全体的に小さくなっており，100\%と60\%も相関 指数の差が殆ど見られず, 高次元になっても相関指数の 上下が曖昧である. 表-6 を確認すると, 相関指数から は軸力の識別が困難であることがわかる。これらの結果 より，ボル卜頭を打撃した場合は，軸力の違いによる特 徵を相関指数によって定量化は困難であり, 小西らの研 究のと同じく識別には向かないという結果が得られた。

\section{(6) 実験結果の考察}

相関次元法によってフラクタル次元を求める際に算 出した相関指数の値による閾值の設定によって, 軸力を 識別することができた．今回の場合，軸力毎に全 9 種の 学習用データから閾值を決定し, 全 6 種の評価用デー 夕を評価した，その結果，100\%と 80\%では完全に識別 できた．アトラクタでは識別の難しかった 60\%と $80 \%$ も 相関指数の值に差があり $80 \%$ と $60 \%$ の打音データ比較し ても識別可能であった．このことから，今後更なる評価 は必要であるが, 相関次元法における相関指数の比較に 
表-6 次元別相関指数の平均值(ボルト頭)

\begin{tabular}{|c|c|c|c|c|c|c|c|c|c|c|c|c|c|c|}
\hline 术ル卜相関指数 & 2 & 3 & 4 & 5 & 6 & 7 & 8 & 9 & 10 & 11 & 12 & 13 & 14 & 15 \\
\hline $100 \%$ & 1.63288 & 2.22832 & 2.83768 & 3.42998 & 4.06643 & 4.24483 & 4.83081 & 4.98559 & 5.48398 & 5.80698 & 5.72168 & 6.06163 & 6.46658 & 6.47763 \\
\hline $80 \%$ & 1.80710 & 2.61755 & 3.41104 & 4.27237 & 4.89386 & 5.51153 & 6.38885 & 6.71495 & 7.21696 & 7.98233 & 7.73785 & 6.70186 & 8.52185 & 8.38780 \\
\hline $60 \%$ & 1.81144 & 2.58542 & 3.32093 & 3.93190 & 4.56755 & 4.80458 & 5.11664 & 5.54010 & 5.22795 & 5.95016 & 5.746600 & 6.47603 & 6.59379 & 6.86703 \\
\hline
\end{tabular}

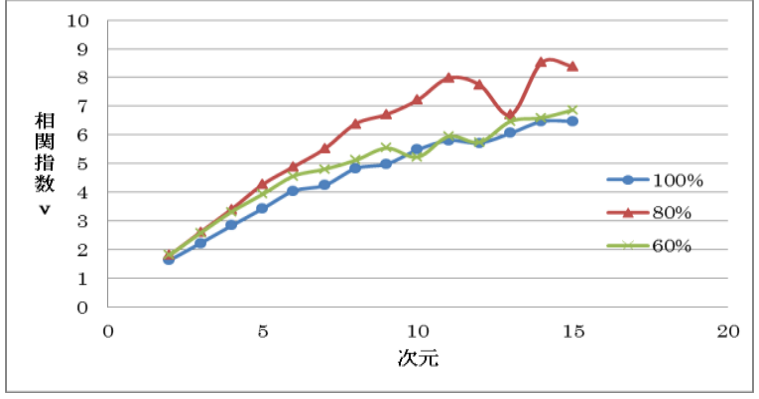

図-12 次元別相関指数平均グラフ (ボルト頭)

\section{よる評価によって，軸力をある程度の精度で識別が可能} であることが分かった。

\section{5. おわりに}

本研究では，ボルトの打音データに対して，カオス時 系列解析法を用いて定量的評価を行い，軸力の識別を行 った. 本研究により得られた知見は以下の通りである.

・相関次元法にて求められる相関指数 $v$ にって, 定量 的評価をすることで，軸力 $80 \%$ の打音データを $100 \%$ と 誤識別したケースが100ケース中 10 ゲース，軸力 $60 \%$ の打音データを $80 \%$ と誤認識したケースが100ケース 中10ケースと精度良く軸力の識別が可能であることが わかった。

・提案した手法においても，ボル卜辺から得られた打音 データは識別に向かないという, 文献6)で得られた結 果と同様の結論が得られた。
今後の課題として，今回実験に使った打音データ数が 少なかったため, より多くのデータを分析し, 識別実験 する必要がある.また，今回考慮しなかった塗装の有無 等条件の違いによる結果の確認を行うことも挙げられる.

\section{参考文献}

1）国土交通省：日本の橋梁の現況, www.mlit.go.jp/ road/sisaku/yobohozen/yobo1_1.pdf，(2013.10.1 現在)

2) 西村昭, 加藤修吾, 神田正孝, 山崎信之, 米谷真 二：既設高力ボルトの各種非破壊検查の特質，橋梁 と基礎 Vol.17, No.11，pp.26-33，1983.11

3) 合原一幸, 池口徹, 山田慶司, 小室元政 : カオス時 系列解析の基礎と応用，産業図書，2000

4) 野村泰稔, 広兼道幸, 古田均, 川谷充郎, 小西日出 幸：打撃音のアトラクタ解析に基づく鋼・コンクリ 一ト合成床版の剥離検出法の開発, 土木学会論文集 A vol64 No1, pp107-120

5) 長嶋弘幸, 馬場良和 : カオス入門 減少解析と数理, 培風館, 1992

6) 小西日出幸, 鈴木直人, 広兼道幸, 中田弘一：パタ ーン認識を用いた高力ボルトの打音による軸力診断 技術の研究, 年次学術講演会, VI-102, 土木学会, pp.203-204, 2013.9

7) 二宮弘 : 様々なカオスとフラクタル, www.gavo.t.u-tokyo.ac.jp/ mine/japanese/soft 12012/no6/pie.pdf，(2013.10.1 現在)

8) 高安秀樹 : フラクタル科学, 朝倉書店, 1987.10

(2013. 7. 12受付)

\section{DIAGNOSIS FOR AXIAL FORCE OF HIGH-STRENGTH BOLTS USING THE CHAOS THEORY}

\section{Michiyuki HIROKANE, Makiko OOE, Hideyuki KONISI and Naoto SUZUKI}

Now, the deterioration of a structure built at period of high economic growth advances, and the number for diagnosis is increasing rapidly. The bridges is no exception, although the number of the 50-year progress bridges in Japan was approximately 15,000 of $9 \%$ of the whole in 2011, they are excepted to increase even to 44,000 which will be equivalent to $28 \%$ in 2021 , and also 84,000 to be gone up also to $53 \%$ in ten years. Even among them, it is necessary to inspect the high power bolt used for the construction of the steel bridge in that regularly because the slack occurs with progress at time. We can carry out without being dangerous activity easily at low cost if we use hammering test. However, this method has a part depending on perception and the experience of the expert, and is insufficient of them. Therefore, we tried to evaluate quantitatively the atteacors that obtained from impact acoustics for the purpose of what even a engineers without enough experience can diagnose. 